\title{
IMPROVING METHODOLOGY OF RISK IDENTIFICATION OF OCCUPATIONAL DANGEROUS
}

\begin{abstract}
In the paper, according to the analysis of statistical data, correlation between the amount of occupational injuries and occupational diseases in Ukraine within last 5 years is defined. Also, using methodology of the International Labor Organization correlcation between the amount of accident fatalities and general number of accidents in Ukraine and EU countries (Austria, Great Britain, Germany, Denmark, Norway, Poland, Hungry, Finland, France) is defined. It is shown that in spite of the positive dynamics of decreasing amount of occupational injuries, the number of occupational diseases in Ukraine always increases. The comparative analysis of the ratio of the number of accident fatalities to the total number of registered accidents showed that, on average, Ukraine exceeds the EU countries by this indicator by 100 times.

It is noted, that such negative indicators (in particular, increasing amount of occupational diseases), may occure because of imperfect methodology for identifying the risks of professional dangerous.

Also, it is ascertained that basing on the existed methodology, the identefication process of occupational dangerous is quite subjective, which reduces objectivity of conducting quantitative assessment. In order to eliminate defined drawnbacks it is first time proposed to use corresponding integral criterion to conduct the process of quantitative risk assessment

To solve this problem authors formulate and propose an algorithm of improving methodology of a process of analysing dangerous and harmful production effects (DHPE) which are the mainest reasons of occupational dangerous.

The proposed algorithm includes implementation of four following successive steps: DHPE identification, indication of their maximum allowed threshold of concentrations (levels), identification of the sources of identified DHPE, esimation of consequences of manifestation.

The improved proposed methodology allows indentify risks of occurrence occupational dangerous in systems "humantechnical system-environment" even on the phase of its designing when dangerous and harmful manufactured factors are unknown yet.
\end{abstract}

Key words: labour protection, industrial safety, occupational diseases, incidents rate, dangerous and harmful production effects, risks of occupational hazards, hazard, identification

Dangerous and harmful production effects (DHPE) are the main causes for real and potential occupational risks to occur and exist. Complete elimination of DHPE is impossible in work conditions, but decline in their negative influence and elimination of certain hazards in some cases are a necessary and achievable task that should be solved by developing and implementing appropriate measures. A thorough analysis of potential dangerous and harmful production effects that might occur at the time of exploiting a technical system is a methodological basis for developing these measures. Safety of both the technical system and worker operating it depends on completeness and objectivity of the analytical procedure.

One of the most important trends of the process of the Ukrainian integration with the European Union is the adaptation of the national laws to the EU legislation. First of all, it concerns the legislative framework on labour protection. Focusing exactly on the field of labour protection is primarily associated with inveteracy, imperfection and sometimes lack of certain national laws and regulations aimed at preventing dangerous and harmful production effects (DHPE) as the main source of the occupational risks (hazards) formation.

In compliance with the International Labour Organization Conventions, EU Regulations and Article 153 of the Labour Code of Ukraine, an owner or a body authorized by him shall provide a safe and harmless work environment at all enterprises, establishments and organizations. Provision of such conditions is usually performed by analyzing potential DHPE (PDHPE) and implementing appropriate measures for their reducing or eliminating. However, as practice shows, it is very problematic to reasonably analyze PDHPE in a legal environment by applying the existing laws and regulations on labour protection.

The first problem is that a single basic instrument that shall be used by a company owner (or a project developer) in Ukraine while analyzing DHPE is wellknown All-Union State Standard (GOST) 12.003 - 74 "Dangerous and Harmful Production Effects. Classification", which was adopted and amended 43 years ago. However, for the time after adopting the document not just the state has ceased to exist on the world map, for enterprises of which this standard was being developed, but new, previously unidentified types of the economic activity and professions with their specific labour conditions and risks have appeared as well.

The second and main problem lies in the absence of a clear developed and legislatively recognized methodology for analyzing potential DHPE in the said AllUnion State Standard (GOST) and even in the national laws and regulations.

This inconsistence of the Ukrainian legal framework conceals certain hazards while developing projects for reconstructing or creating new technical systems when a project developer has to identify potential DHPE at his own subjective discretion, to determine their origin source, their after-effects, thus imminently building certain risks (failures) in all the technology implementation phases.

The problems of improvement and development of the occupations risks (hazards) analysis and assessment methodology, and improvement of job evaluation 
methods under the work conditions were considered in the following final studies [1-4]. The analysis of literature sources revealed that despite a great number of suggested methods there is nothing that we can use in practice while analyzing hazards (risks) of technical systems being at the designing stage.

The purpose of this work is to set aspects of the methodology for analyzing dangerous and harmful production effects.

To achieve the said goal in the work, the following tasks shall be completed: DHPE;

- updating of the methodology for analyzing

- interpretation of components of the integral criterion of the quantitative risk-based assessment of hazards;

- analysis of available methods to identify DHPE;

- setting of aspects of the methodology for analyzing DHPE.

The accidents analysis carried out on the basis of the Ukrainian enterprises reveals that roughly a half of their total number occurs due to the presence of dangerous and harmful production effects [5].

According to the data of the International Labour Organization, circa 1200 people die every day due to industrial accidents, and almost by 5 times more -5400 people die from occupational diseases. Furthermore, about 160 million cases of occupational diseases are registered every year. In every third case, a disease causes the loss of capacity to labour for 4 and more working days; and a total number of industrial accidents and occupational diseases over the world is assessed at 470 million cases per year.

The situation in Ukraine stays questionable either due to the incidents rate and cases of occupational diseases. The ratio of the incidents rate and occupational diseases has sustainably been increasing for last 5 years despite a volatile economic situation (fig. 1).

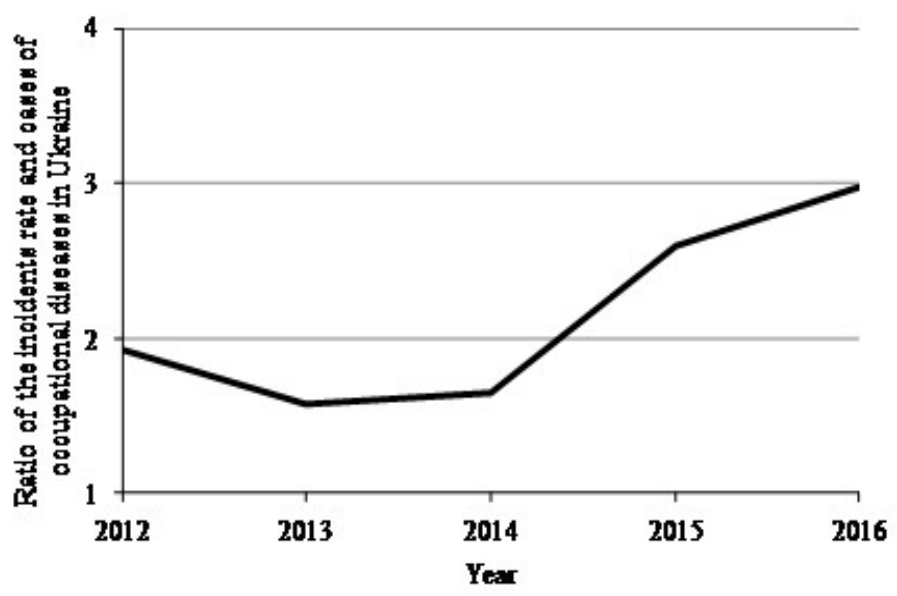

Fig. 1 - Ratio of the incidents rate and cases of occupational diseases in Ukraine [6]

By the main indicators of the severity of injury, such as the coefficient of fatal cases frequency $\left(\mathrm{C}_{\mathrm{fc}}\right)$, the ratio of number of fatal accidents to the total number of registered accidents, Ukraine is far ahead of the EU (Tab. 1) $[9]$
Table 1. The ratio of number of fatal accidents to the total number of registered accidents in the $E U$ and in Ukraine

\begin{tabular}{||c||c||}
\hline Countries & The ratio \\
\hline \hline Austria & 0,057 \\
\hline \hline Great Britain & 0,014 \\
\hline \hline Germany & 0,8 \\
\hline \hline Denmark & 0,024 \\
\hline \hline Norway & 0,8 \\
\hline \hline Poland & 0,7 \\
\hline \hline Hungary & 0,54 \\
\hline \hline Ukraine & 10 \\
\hline \hline Finland & 0,07 \\
\hline France & 0,16 \\
\hline
\end{tabular}

So, how can we explain such a ratio? After all, relevant bodies carry out a control of labour protection at enterprises with the same diligence precisely upon these indicators.

In the authors 'opinion, one of the most important causes for such a situation to occur is a subjective approach (misconception) to the DHPE analytical procedure at the stage of design of technical systems when dangerous and harmful production effects of a target of research (technical system) are still unknown.

It is worth mentioning that dangerous production effects, which are the main causes of the incidents rate, are subject to a more detailed forecast than harmful production effects that can change several times in a rather wide scope (increase of the dust level, air pollution, noise, vibration and so forth), and facilitate the contraction and development of employees 'occupational diseases.

Increase in the proportion of occupational diseases in the total accident rate indicates the fact of necessity to develop and obligatorily implement an objective, scientifically based methodology for analyzing DHPE in terms of legislation in all types of the industrial activity as the fundamental principle for establishing safe technical systems.

But, running the DHPE analytical procedure is obviously not sufficient to establish a safe technical system. Achieving the safety implies, first of all, the quantitative occupational risk assessment, i.e. a work environment and possible "human factor" displays. The next phase is implementation of a system of respective measures for minimizing and eliminating the said risks on the basis of a gained assessment.

In the assessment practice, rating of targets of research (assessment of occupational hazards in this case) that ensures more accurate information acquisition becomes more and more significant. So, occupational risks are identified not by means of one criterion, but two at least:

- work conditions (environment), e.g. present chemicals in the air of a work area, noise levels, vibration, light and so forth;

- "human factor", etc.

Thus, the quantitative risk-based assessment of occupational hazards can be achieved by determining an integral criterion that consists of a complex criterion of 
assessment of possible "human factor" displays $\left(\mathbf{C}_{\text {he }}\right)$ and a complex criterion of assessment of work conditions $\left(\mathbf{C}_{\mathbf{w c}}\right) . \mathbf{C}_{\mathrm{he}}$ should consider stochastic and non-stochastic factors that cause human misactions and impact the human behaviour in the workflow course [2].

The said complex criterion will characterize the level of possible hazards (incidents rate) at a corresponding enterprise while applying a specific operational procedure.

The complex criterion of assessment of work conditions could be interpreted as a set of criteria of the quantitative assessment of potential (unknown) DHPE that are specific to a particular technical system.

Defining $\mathbf{C}_{\mathbf{w c}}$ let fairly estimate a workplace basing on the presence and significance of certain PDHPE influence on a worker.

Use of the integral criterion allows achieving the compliance of the assessment results on risks of occupational hazards with the highest international labour protection requirements.

The integral criterion for assessing risks of occupational hazards [2] shall be determined on the basis of the PDHPE preliminary analysis, considering the most adverse conditions that might occur while applying an operational procedure and be confirmed while certifying workplaces upon the indicators of hazard and harm.

In Ukraine, at this period, a single instrument used for detecting and investigating dangerous and harmful production effects at work is [7]. In compliance with the specified recommendations, identification of specific DHPE with the further comparison of received and relevant standard figures by means of laboratory (instrumental) surveys shall be carried out at each workplace not less than once in five years. According to the work environment, a workplace shall be estimated in view of the influence of all working-environment factors and manufacturing variables on workers, general factors of technical and organizational levels of work conditions and health damage risk level. On grounds of the integrated assessment, workplaces are classified according to one of the specified types of work environment:

1. With exceptionally harmful and arduous work conditions;

2. With harmful and arduous work conditions;

3. With harmful work conditions.

Internationally, similar methods are applied while estimating workplaces, but the primary attention is paid on identification and ranging of such hazards that may cause workers` injuries.

The main disadvantages of modern methods on certifying workplaces and identifying risks of occupational hazards are as follows:

- subjectivity, especially in the approach on defining similarity and permanence (volatility) of jobs;

- absence of an integrated approach (considering the "human factor");

- great time, finance and work consumption for their implementation;

- limited use.

According to some methods, identification of dangerous and harmful production effects at workplaces similar in work conditions is carried out on the basis of data received in the course of certification of every fifth workplace. However, it is wrong to believe that work conditions at workplaces of employees with alike professions are similar, even at one enterprise (in one building, construction, department, section, etc.) Moreover, organization peculiarities and operational procedures also impact the certification results. Instrumental (objective) measurements of DHPE compose a quarter at the most of the information about occupational hazards identified at workplaces, and the rest depends on experience, professional competence and diligence of specialists who certify them.

The limited use of available methods lies in the impossibility of their implementation while certifying workplaces of technical systems that are at the stage of design or reconstruction as PDHPE are unknown at these stages and cannot be investigated instrumentally (objectively). But, it is the direct violation of the state and international standards requirements to the assessment of occupational hazards and health, and creates failures at the fundamental stage of the technical system establishment - its designing.

Thus, the available national and world laws and regulation on labour protection are imperfect and do not provide any tools to carry out the PHDPE analytical procedure as an integral part of the occupational risk assessment system for technological ensembles being designed (established).

The authors suggested a methodology for analyzing potential DHPE [8] that may be applied in establishing new or certifying available workplaces at technical systems. The analytical procedure is a ground for performing the objective criterion assessment of risks of hazards related to the work environment, and stipulates the accomplishment of the following stages:

- identification of dangerous and harmful production effects;

- specification of their maximum permissible concentrations (levels);

- assessment of DHPE after-effects.

Identification is a procedure on identifying an unknown object by its equating to the known on the basis of coincidence of features.

The identification procedure at the designing stage is always approximate as it is impossible to equate a known (real) object with the unknown (virtual, being designed) due to this object's physical lack of any quantitative (objective) features. So, at this stage, one can equate objects just if their qualitative (nominal) features coincide. Nominal features of a target of research are formed by a project developer in the course of study of similar existing technical systems.

Identification of potential dangerous and harmful production effects implies the identification of factors classified in All-Union State Standard (GOST) 12.00374 , which can be on a target of research (object being designed), by equating them according to their nominal features.

Assessment criteria of specific identified DHPE (levels of noise, vibration, dust, light, etc.) are their maximum permissible concentrations (levels) specified in relevant instruments. The methodology for identifying assessment criteria for those DHPE that are not standardized (moving elements of industrial facilities, increased 
value of voltage in the electric circuit, the closing of which can occur through a human body, increased static electricity level, etc.) is one of viable lines of research of the authors.

Identifying origin sources and understanding after-effects of identified PDHPE allow excluding possible mistakes that can be made in a studied technical system model at the stage of its designing, and making it highly safe and effective for a worker who will use it in the future. conclusions:

Performed studies allow us to make the following

1. Growth of a number of occupational diseases in a total scope of accidents highlights the fact of necessity to develop and obligatorily implement an objective, scientifically based methodology for analyzing DHPE in terms of legislation in all types of the industrial activity as the fundamental principle for establishing safe technical systems.

2. DHPE analysis is an integral fundamental phase in the course of the quantitative assessment of risks of occupational hazards.

3. The known national and world methods for identifying PDHPE (certification of workplaces according to the work environment) are imperfect and can be applied to technical systems (workplaces) which are being designed.

4. The suggested methodology allows identifying unknown potential DHPE at the stage of design of technical systems, increasing the general safety level, and as a result, reducing future risks of occupational hazards at the time of technical systems exploitation.

\section{LITERATURE}

1. Bochkovskyi, A. P. (2016). Teoretychni aspekty universalizatsiyi otsinky profesiynoho ryzyku v systemakh upravlinnya okhoronoyu pratsi [Theoretical aspects of univarsalization of professional risk evolution in occupational health and management systems]. Bulletin of the Lviv State University of Life Safety, 14, $134-151$. doi: $10.13140 / R$ R.2.2.22043.87848

2. Bochkovskyi, A. P. (2015). "Lyudskyy faktor» ta ryzyk vynyknennya nebezpek: vypadkovist chy zakonomirnist. [The "human factor" and the risk of hazard: coincidence or regularity]. Yurydychna literature, 132.

3. Vodyanyk A. O. (2008). Metodolohichni osnovy vrakhuvannya faktora ryzyku v profilaktytsi vyrobnychoho travmatyzmu [Methodological foundations for hiccuping the risk factor in occupational traumatism]. National Research Institute for Occupational Safety and Health, Kiev. - $300 \mathrm{s.}$

4. Kassu Jilcha, Daniel Kitaw (2017). Industrial occupational safety and health innovation for sustainable development. Engineering Science and Technology, an International Journal, 20, 372 - 380. Available at: http://doi.org/10.1016/j.jestch.2016.10.011

5. The International Labour Organization. Available at: http://www.ilo.org/global/statistics-and-databases/lang-en/index.htm.

6. Analysis of accident insurance and occupational diseases in Ukraine in 2012 - 2016 rr. Social Insurance Fund of accidents and occupational diseases in Ukraine. Available at: http://www.social.org.ua/activity/stat

7. The procedure of certification of workplaces under labor conditions. Available at: http://zakon2.rada.gov.ua/laws/show/442-92-\%D0\%BF

8. Bochkovskyi, A. P. (2014). Teoretychni aspekty metodolohiyi analizu nebezpechnykh $i$ shkidlyvykh vyrobnychykh faktoriv [Theoretical aspects of the methodology of analysis of hazardous and harmful production factors]. Collection of scientific works ONAFT, 46, 285 - 291. doi: 10.13140/RG.2.1.5073.8969

9. Bochkovskyi, A. P., Sapozhnikova, N.Yu., Gogunskii, V. D. (7017). Legal and organizational issues of improving the labor protection and industrial safety level at the Ukrainian enterprises. Scientific Bulletin of National Mining University, 5 (161), 100-108. doi:10.13140/RG.2.2.33613.23528 (Scopus)

\section{А.П. БОЧКОВСЬКИЙ ${ }^{1}$, к.т.н., доцент, Н.Ю. САПОЖНІКОВА², к.т.Н., ст.викладач \\ ${ }^{1}$ Одеський Національний Політехнічний Університет, Одеса \\ ${ }^{2}$ Одеська Національна Академія Харчових Технологій, Одеса \\ УДОСКОНАЛЕННЯ МЕТОДОЛОГІЇ ДЕНТИФІКАЦІЇ РИЗИКІВ ВИНИКНЕННЯ ПРОФЕСІЙНИХ НЕБЕЗПЕК}

\footnotetext{
Анотація

В статті, на основі аналізу статистичних даних, визначено співвідношення кількості випадків виробничого травматизму та професійних захворювань в Украйні за останні 5 років. Також визначено співвідношення кількості нещасних випадків зі смертельним наслідком до загального числа зареєстрованих нещасних випадків в Україні та країнах СС (Австрія, Велика Британія, Германія, Данія, Норвегія, Польща, Угорщина, Фінляндія, Франція) за методикою Міжнародної Організаиї̈ Прачі. Встановлено, що на тлі позитивної динаміки зменшення кількості випадків виробничого травматизму в Україні, кількість випадків професійних захворювань постійно зростає. Порівняльний аналіз співвідношення кількості нещасних випадків зі смертельним наслідком до загального числа зареєстрованих нещасних випадків показав, що Украйна в середньому випереджає країни СС за иим показником у 100 разів.

В рамках дослідження зазначено, щзо така негативна динаміка в Украйні (зокрема, зростання кількості професійних захворювань), може бути обумовлена недосконалою методологією ідентифікаиії ризиків виникнення професійних небезпек.

Зазначено, щзо в рамках існуючої методології ідентифікація професійних небезпек є доволі суб'єктивним процесом, що в свою чергу знижує об' єктивність отримання кількісної оцінки ризиків. 3 метою усунення виявлених недоліків вперше запропоновано використовувати, для проведення процесу кількісної оџінки ризиків, відповідний інтегральний критерій.
} 
Для вирішення поставленого завдання, авторами вперше сформульовано і запропоновано алгоритм удосконаленоі методології прочесу аналізу небезпечних і шкідливих виробничих факторів (НШВФ), які є основними причинами виникнення професійних небезпек. Даний алгоритм передбачає послідовне виконання наступних чотирьох етапів: ідентифікаиія НШВФ, зазначення їх гранично-допустимих концентрачій (рівнів), встановлення джерел виникнення ідентифікованих НШВФ, оцінка наслідків прояву НШВФ.

Запропонована удосконалена методологія дозволяє ідентифікувати ризики виникнення професійних небезпек в системах «людина-технічна система-середовище» навіть на стадії їх проектування, коли небезпечні та шкідливі виробничі фактори ще невідомі.

Ключові слова: охорона праці, промислова безпека, професійні захворювання, виробничий травматизм, небезпечні та шкідливі виробничі фактори, ризик виникнення професійних небезпек, небезпека, ідентифікація

\section{ЛІТЕРАТУРА}

1. Бочковський, А.П. Теоретичні аспекти універсалізації очінки професійного ризику в системах управління охороною праці [Текст] / А.П. Бочковський // Вісник Львівського державного університету безпеки жситтєдіяльності, 2016, № 14. - C.134-151 doi: 10.13140/RG.2.2.22043.87848

2. Бочковський, А.П. «Людський фактор» та ризик виникнення небезпек: випадковість чи закономірність. [Монографія]. Одеса, Юридична література, 2015. - С. 136.

3. Водяник, А. О. Методологічні основи врахування фактора ризику в профілактиці виробничого травматизму [Текст] : Дис. ... д-р. техн. наук. : 05.26.01/ А.О. Водяник. -Київ, 2008. - С. 300

4. Kassu Jilcha, Daniel Kitaw. Industrial occupational safety and health innovation for sustainable development [Text] / Kassu Jilcha, Daniel Kitaw // Engineering Science and Technology, an International Journal, 2017, № 20. - C. 372 - 380. Режим достуny: http://doi.org/10.1016/j.jestch.2016.10.011

5. Міжнародна організаиія праиі. [Електронний ресурс] / Режим доступy: http://www.ilo.org/global/statistics-anddatabases/lang--en/index.htm.

6. Аналіз страхових нещасних випадків та професійних захворювань в Украйні в 2012 - 2016 рр. Фонд сочіального страхування від нещасних випадків на виробництві та професійних захворювань в Украйні [Електронний ресурс] / Режим достуny: http://www.social.org.ua/activity/stat

7. Про порядок проведення атестації робочих місиь за умовами праџі [Електронний ресурс] / Режим доступу: http://zakon2.rada.gov.ua/laws/show/442-92-\%D0\%BF

8. Бочковський, А.П. Теоретичні аспекти методології аналізу небезпечних і шкідливих виробничих факторів. [Текст] / А.П. Бочковський // Наукові прачі Одеської Національної Академії Харчових Технологій, 2014, № 46. - С. 285-291 doi: $10.13140 / R G \cdot 2.1 .5073 .8969$

9. Bochkovskyi, A. P. Legal and organizational issues of improving the labor protection and industrial safety level at the Ukrainian enterprises [Text] | A.P. Bochkovskyi, N.Yu. Sapozhnikova, V. D.Gogunskii II Scientific Bulletin of National Mining University, 2017. № 5 (161). - P.100-108 doi:10.13140/RG.2.2.33613.23528 (Scopus)

\section{ЗЕРНОБОБОВЫЕ КУЛЬТУРЫ - СПРОС РАСТЕТ, Часть 2.}

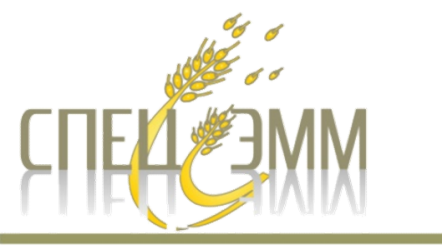

\section{Нут - перспективная культура. \\ Общие положения}

После ознакомления с такой культурой, как $\boldsymbol{\mu y \boldsymbol { m }}$, я с большой вероятностью могу прогнозировать, что в ближайшие годы в Украине нуm будет занимать не менее 1-1,5 млн. га. Увеличение площади под еще совсем недавно незнакомую культуру для украинского агронома объясняется двумя факторами - ликвидностью семян нуma на рынке и благоприятными условиями произрастания этой культуры на украинской земле. Семена нута имеют высокую кормовую, а еще в большей мере, пищевую ценность. В их составе около $30 \%$ белка и до 7\% жира, более $50 \%$ безазотистых веществ, а также $\mathrm{Ca}, \mathrm{Mg}, \mathrm{Fe}, \mathrm{Zn}$. Причем белок по аминокислотному составу близок к идеальному и мало чем отличается от яичного белка. Особая ценность белка нута в том, что он содержит такие незаменимые аминокислоты, как метионин и триптофан в количестве 340 и 220 мг/100 г продукта. По совокупности полезных веществ семена нута находятся в лидерах среди многочисленных продуктов растительного происхождения. Биологическая ценность белка нута 52-78\%, коэффициент усвояемости 80-82\%. Одна из важнейших особенностей нута а (в отличие, к примеру, от сои) - он не содержит антипитательных веществ, требующих инактивации высокими температурами, и может употребляться в пищу в нативном виде, т.е. в таком виде, в каком убирается с поля.

Латинское название «нут» - Cicer. Предполагают, что оно произошло от греческого «Kikus», что значит «сила», или «мощь». Не исключено, что $\boldsymbol{\mu y \boldsymbol { m }}$ так называли за то, что он самая засухоустойчивая из всех зернобобовых культур. На Ближнем Востоке $\boldsymbol{н y m}$ начали возделывать уже 7500 лет назад.

За 10 лет с 1985 по 1995 гг. производство 